University of Nebraska - Lincoln

DigitalCommons@University of Nebraska - Lincoln

\title{
Knowledge Gained from Video-Monitoring Grassland Passerine Nests
}

P. J. Pietz

USGS Northern Prairie Wildlife Research Center, ppietz@usgs.gov

D.A. Granfors

U.S. Fish and Wildlife Service, diane_granfors@fws.gov

C.A. Ribic

Wisconsin Cooperative Wildlife Research Unit, caribic@wisc.edu

F. R. Thompson

University of Missouri, frthompson@fs.fed.us

Follow this and additional works at: https://digitalcommons.unl.edu/usgsnpwrc

Part of the Other International and Area Studies Commons

Pietz, P. J.; Granfors, D.A.; Ribic, C.A.; and Thompson, F. R., "Knowledge Gained from Video-Monitoring Grassland Passerine Nests" (2012). USGS Northern Prairie Wildlife Research Center. 254.

https://digitalcommons.unl.edu/usgsnpwrc/254

This Article is brought to you for free and open access by the US Geological Survey at DigitalCommons@University of Nebraska - Lincoln. It has been accepted for inclusion in USGS Northern Prairie Wildlife Research Center by an authorized administrator of DigitalCommons@University of Nebraska - Lincoln. 


\section{Knowledge Gained from Video-Monitoring Grassland Passerine Nests}

Abstract. In the mid-1990s, researchers began to adapt miniature cameras to video-record activities at cryptic passerine nests in grasslands. In the subsequent decade, use of these video surveillance systems spread dramatically, leading to major strides in our knowledge of nest predation and nesting ecology of many species. Studies using video nest surveillance have helped overturn or substantiate many long-standing assumptions and provided insights on a wide range of topics. For example, researchers using video data have (1) identified an extensive and highly dynamic predator community in grasslands that varies both temporally (e.g., by time of day, nest age, season, year) and spatially (e.g., by habitat, edge, latitude); (2) shown that sign at nests is unreliable for assigning predator types and sometimes nest fates; (3) contributed to the

$\mathrm{n}$ the 1990 s, the plight of grassland birds received increased attention (Johnson and Schwartz 1993, Knopf 1994, Johnson and Igl 1995), as researchers began to recognize that grassland species were showing "steeper, more consistent, and more geographically wide-spread declines than any other behavioral or ecological guild" of North American birds (Knopf 1994:251). Many grassland passerine populations had been declining for decades understanding of the risks and rewards of nest defense; and (4) provided information on basic breeding biology (e.g., fledging ages, patterns of incubation and brooding, and male/female roles in parental care). Using examples from grasslands, we highlight accumulated knowledge about activities at the nest documented with video surveillance; we also discuss the implications of this knowledge for our understanding of avian ecology. Like all tools, video nest surveillance has potential limitations, and users must take precautions to minimize possible sources of bias in data collection and interpretation.

Key Words: avian behavior, breeding ecology, camera, grassland, nest monitor, nest predators, passerine, video surveillance.

(Peterjohn and Sauer 1993, Herkert 1995, Igl and Johnson 1997), and it was thought that high rates of nest predation could be contributing to these declines (Basore et al. 1986, Martin 1993). At that time, there were few data on the identity of nest predators of grassland passerines. Predator sign at grassland duck nests had been studied intensively (Sargeant et al. 1993, 1998); however, at passerine nests, assignment of nest fates and identity

Fietz, P. J., D. A. Granfors, and C. A. Ribic. 2012. Knowledge gained from video-monitoring grassland passerine nests. Pp. 3-22 in C. A. Ribic, F. R. Thompson III, and P. J. Pietz (editors). Video surveillance of nesting birds. Studies in Avian Biology (no. 43), University of California Press, Berkeley, CA. 

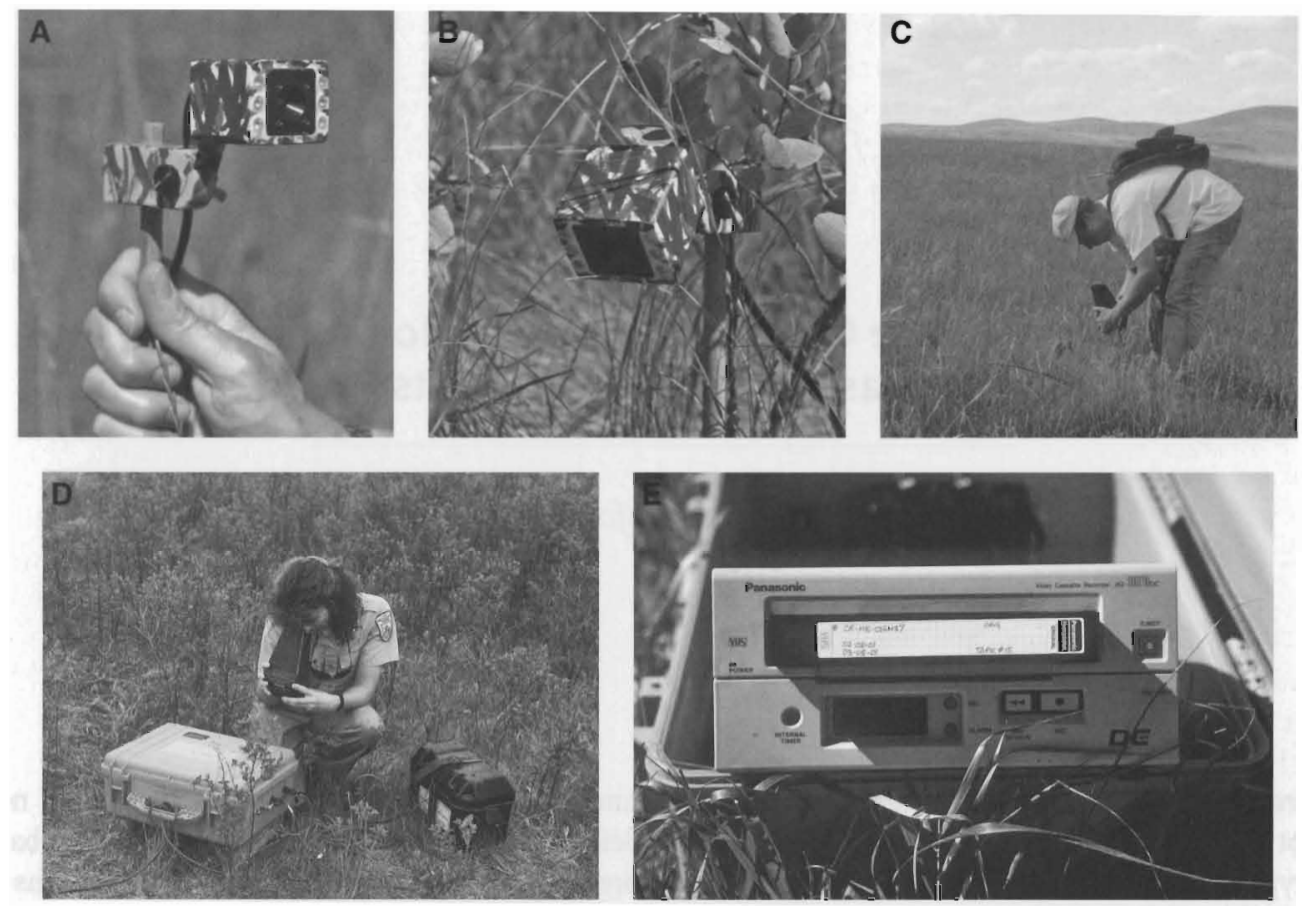

Figure 1.1. Components of video surveillance system used during 1996-2001 to monitor grassland passerine nests in North Dakota and western Minnesota: (a) camera with LEDs around lens; housing and mounting bracket painted to blend with vegetation; (b) camera mounted on wooden dowel above a nest; (c) after placing a camera, R. J. Fletcher, Jr., checks the camera view with a handheld monitor at the nest site; (d) E. M. Madden remotely checks a nest with handheld monitor attached to VCR; VCR is inside weatherproof case with external connectors for battery and monitor; (e) weatherproof case open and VCR tilted up to change videotape.

of predators were usually based on assumptions (Best 1978, Wray et al. 1982, Vickery et al. 1992). Often, when a passerine nest was revisited, only an empty bowl remained, with few or no clues as to what had happened (Hussell 1974, Major and Gowing 1994).

Determining fates of grassland bird nests by direct observation generally is not feasible. Nests of many species of grassland birds are well hidden in vegetation, making it difficult or impossible to view nest contents from a distance, and are in open terrain, making unobtrusive observation a challenge. Predator communities often include both nocturnal and diurnal nest predators, which would require 24 -hr surveillance. Identifying fates and predators of active grassland passerine nests could not be adequately addressed using artificial nests, still cameras, or conspicuous equipment (Pietz and Granfors 2000a). The need for a new tool was evident.

In 1996, Pietz and Granfors (2000a) began testing a video surveillance system (hereafter camera system) specifically designed to monitor grassland passerine nests. This first system used a blackand-white camera, about $4 \times 4 \mathrm{~cm}$ on each side, with infrared (940-950 nm) light-emitting diodes (LEDs) to cryptically illuminate the nest area at night (Fig. 1.1a). Cameras had to be close to the nests (typically $<30 \mathrm{~cm}$ ) to record activity at the nests and the fate of nest contents without vegetation obstructing the view (Fig. 1.1b). Cameras, in waterproof housings, were made as small as possible to minimize disturbance to the nesting birds and to avoid attracting other animals. The camera angle and placement were adjusted at the nest with the aid of a handheld video monitor (Fig. 1.1c). The camera was connected by cable to a time-lapse videocassette recorder (VCR) and battery (Fig. 1.1d) about 40-50 $\mathrm{m}$ away. VCRs were set to record continuously and capture about 4 images/sec because early trials showed that some predation events took only a fraction of a second. At this recording speed, videotapes had to be changed (Fig. 1.1e) daily. The person changing the tape connected a handheld video monitor to the VCR (Fig. 1.1d) to determine (with reasonable certainty) if the nest was 
still active, thus eliminating the need to physically revisit the nest. The camera was left in place until the nest failed or succeeded (i.e., fledged young). Camera systems were deployed as far apart as possible within and among study sites to reduce the chance that individual predators with large home ranges [e.g., fox (Vulpes spp.), coyote (Canis latrans)] would encounter more than one nest with a camera.

From the mid-1990s through the early 2000s, these or similar camera systems were used in a variety of grassland bird studies (Winter et al. 2000, Renfrew and Ribic 2003, Klug 2005, Grant et al. 2006). The purpose of this paper is to use this body of work and the papers in this volume to provide an overview of the contributions these camera systems have made to the understanding of grassland bird ecology. We include updated test results for some of the questions explored with smaller data sets by Pietz and Granfors (2000a). With these sources of information, we address the following topics: fates of nests, eggs, and nestlings; predator identification and predator ecology; standard methods of data collection and analyses; predator behavior and predator-prey interactions; and parental and nestling behaviors. We close with caveats related to the use of cameras at nests and the interpretation of data collected with camera systems.

\section{FATES OF NESTS AND NEST CONTENTS}

Studies using video nest surveillance (hereafter camera studies) confirmed that predation was the leading cause of nest failure for grassland passerines (Pietz and Granfors 2000a, Klug 2005, Renfrew et al. 2005, Ribic et al., chapter 10, this volume). In addition, video data revealed that some successful nests (i.e., at least one young fledged) lost part of their contents to predators (i.e., partial predation) (Pietz and Granfors 2005). Results from studies in North Dakota and Minnesota showed that predation not only accounted for most nest losses (Table 1.1) but also was the leading cause of mortality among nestlings (Table 1.2).

Camera studies revealed that partial predation sometimes led to nest abandonment by the parents [e.g., in Northern Bobwhite (Colinus virginianus); Ellis-Felege et al., chapter 13, this volume]. Abandonment also occurred at some passerine nests subjected to cowbird parasitism and removal of host eggs (Hill and Sealy 1994, Romig and Crawford 1995). Video data allow researchers to link proximate events (e.g., egg removal) with nest fates; however, classifying such nests may then become ambiguous using current terminology. For instance, in the examples above, should the cause of nest failure be considered predation or parental abandonment?

Parental abandonment also may be caused by deployment of cameras near nests, particularly during the egg stage (Pietz and Granfors 2000a). Nest abandonment that occurred $<1$ day after camera deployment was assumed to be induced by the nesting birds' intolerance for the presence of the camera, the disturbance caused while setting up the camera system, or both. In a sample of passerine nests monitored during 1996-2001, 31 of 37 abandonments occurred within 1 day of camera deployment and, thus, were considered to be camera induced (Table 1.1). In the 1996-2001 sample, nearly $22 \%$ of 137 nests were abandoned within 1 day when the camera system was deployed during egg laying or incubation; only one such abandonment occurred $(<2 \%)$ among 51 nests when the camera system was deployed during or after hatch. Nest failures attributed to cameras are discussed in the "Caveats" section.

In addition to predation, video surveillance revealed factors leading to nest failure or loss of eggs or nestlings that may have been misclassified as predation in the absence of video data (Pietz and Granfors 2000a). For example, two Clay-colored Sparrow (Spizella pallida) nests in small shrubs gradually tipped over as the nestlings grew, and the nestlings suddenly fell out. Unless the nestlings were still present (e.g., on the ground) when the observer returned to check the nest, the observer would have found only an empty, disheveled nest that appeared to have been torn from the shrub by a predator.

Video data also showed that some nestlings left the nest prematurely, seemingly on their own accord (here we define "prematurely" as earlier than expected based on fledging ages from undisturbed nests). For example, at a cameramonitored Savannah Sparrow (Passerculus sandwichensis) nest in Minnesota, a small plains gartersnake (Thamnophis radix) attempted to remove 7-d-old nestlings but failed. One nestling left the nest during the snake's visit and the remaining four nestlings departed within the next $1.5 \mathrm{hr}$. Video data from undisturbed nests showed that 
TABLE 1.1

Fates of 188 grassland passerine nests monitored with video surveillance systems in North Dakota and Minnesota during 1996-2001.

\begin{tabular}{|c|c|c|c|c|c|c|c|c|}
\hline \multirow[b]{2}{*}{ Common name } & \multirow[b]{2}{*}{ Scientific name } & \multirow[b]{2}{*}{ Total nests } & \multirow[b]{2}{*}{ Abandoned } & \multicolumn{2}{|c|}{ Destroyed } & \multirow[b]{2}{*}{ Other loss } & \multirow[b]{2}{*}{ Censored } & \multirow[b]{2}{*}{ Fledged } \\
\hline & & & & Depredated & Other & & & \\
\hline $\begin{array}{l}\text { Common Yellow- } \\
\text { throat }\end{array}$ & Geothlypis trichas & 1 & & 1 & & & & \\
\hline Clay-colored Sparrow & Spizella pallida & 75 & 15 & 17 & 2 & 1 & 6 & 34 \\
\hline Vesper's Sparrow & Pooecetes gramineus & 6 & & 4 & & & & 2 \\
\hline Savannah Sparrow & Passerculus sandwichensis & 59 & 9 & 15 & 1 & & 8 & 26 \\
\hline Grasshopper Sparrow & Ammodramus savannarum & 4 & 1 & & & & & 3 \\
\hline Baird's Sparrow & Ammodramus bairdii & 3 & 1 & 1 & & & & 1 \\
\hline Le Conte's Sparrow & Ammodramus leconteii & 2 & & & & 1 & & 1 \\
\hline Song Sparrow & Melospiza melodia & 2 & & 1 & & & & 1 \\
\hline $\begin{array}{l}\text { Chestnut-collared } \\
\text { Longspur }\end{array}$ & Calcarius ornatus & 9 & 2 & 4 & & & & 3 \\
\hline Bobolink & Dolichonyx oryzivorus & 23 & 7 & 4 & & & & 12 \\
\hline Red-winged Blackbird & Agelaius phoeniceus & 1 & & 1 & & & & \\
\hline Western Meadowlark & Sturnella neglecta & 3 & 2 & 1 & & & & \\
\hline Total nests & & 188 & 37 & 49 & 3 & 2 & 14 & 83 \\
\hline
\end{tabular}

NOTES: Nest abandonment $<1 \mathrm{~d}$ after camera deployment was assumed to be induced by the nesting birds' intolerance for the camera's presence and/or disturbance during camera-system setup. Thirty-one nest abandonments were classified as camera induced. In four abandonments that occurred later, nestlings may have been orphaned (two Clay-colored Sparrow nests, one Savannah Sparrow nest, one Bobolink nest). Two nest abandonments (one Clay-colored Sparrow, one Savannah Sparrow) occurred after Brown-headed Cowbirds punctured or removed host eggs and (in the latter case) laid a cowbird egg. Destroyed nests that were not depredated included one Clay-colored Sparrow nest from which a Brown-headed Cowbird tossed out the nestlings (see Notes to Table 1.2), one Clay-colored Sparrow nest from which the young fell out as the nest tipped over, and one Savannah Sparrow nest from which an adult Savannah Sparrow (presumed parent) tossed out the young. Other nest losses included nestling starvation (one Clay-colored Sparrow nest) and all eggs addled (one Le Conte's Sparrow nest). Censored indicates that the nest fate was not captured on video, either because equipment failed (six nests) or because the camera was removed before the nest fate was determined (eight nests). Nests were classified as fledged if at least one nestling left the nest. 
TABLE 1.2

Fates of eggs and nestlings at grassland passerine nests monitored with video surveillance systems in North Dakota and Minnesota during 1996-2001.

\begin{tabular}{|c|c|c|c|c|c|}
\hline \multirow[b]{2}{*}{ Fate } & \multirow[b]{2}{*}{ Cause } & \multicolumn{2}{|c|}{ Eggs } & \multicolumn{2}{|c|}{ Nestlings } \\
\hline & & Host & Cowbird & Host & Cowbird \\
\hline \multirow[t]{7}{*}{ Destroyed } & Predator & 72 & & 140 & 11 \\
\hline & Cowbird & 6 & & 10 & \\
\hline & Parent & 1 & & 2 & \\
\hline & Starvation & & & 21 & 1 \\
\hline & Tipped out & & & 5 & \\
\hline & Weather & & & 2 & \\
\hline & Unknown & 1 & & 1 & \\
\hline \multirow[t]{4}{*}{ Abandoned } & Camera & 117 & 3 & 3 & \\
\hline & Predator & 2 & & & \\
\hline & Cowbird & 3 & 2 & & \\
\hline & Unknown & 1 & & 16 & \\
\hline \multirow[t]{2}{*}{ Unhatched } & Addled & 43 & 4 & & \\
\hline & Laid too late & & 1 & & \\
\hline \multirow[t]{4}{*}{ Hatch/fledge } & Normal & 353 & 13 & 216 & 2 \\
\hline & $\begin{array}{l}\text { Forced by } \\
\text { predator }\end{array}$ & & & 22 & 1 \\
\hline & $\begin{array}{l}\text { Forced by } \\
\text { observer }\end{array}$ & & & 7 & \\
\hline & Tipped out & & & & 1 \\
\hline
\end{tabular}

NOTES: Although Brown-headed Cowbird is listed as a "predator" in Tables 1.3 and 1.4, it is listed separately from predators as a cause of loss both here and in Table 1.1 for the benefit of those interested specifically in cowbird effects. Cowbird = Brown-headed Cowbird throughout this table. Destroyed tipped-out nestlings include four 2-d-old Clay-colored Sparrow nestlings which died after falling out of their nest (47 cm above ground level) as it tipped completely over, and one 5-d-old Clay-colored Sparrow nestling which fell out as the nest $(44 \mathrm{~cm}$ high) tipped over on its side. Abandonments $<1 \mathrm{~d}$ after camera deployment were classified as caused by cameras. Hatch/fledge tipped-out nestling was from a Clay-colored Sparrow nest $(44 \mathrm{~cm}$ high) that had been gradually tipping sideways; an 8-d-old host young left on its own but, a few hours later, the nest bowl tipped over and an 8-d-old cowbird fell out.

Savannah Sparrow nestlings usually do not fledge until they are 9-10 days old (Pietz et al., chapter 4, this volume).

Many cases of "forced fledging" (sensu Pietz and Granfors 2000a) took place while a predator was still at the nest. In such cases, the young were clearly motivated to leave the nest by the presence of the predator, but classifications of nest and nestling fates remain ambiguous. At one Savannah Sparrow nest in North Dakota, a 7-d-old nestling fled the nest while a white-tailed deer (Odocoileus virginianus) was eating its nest mates (Pietz and Granfors 2000b). Technically, the young bird that left the nest would have been considered a fledgling. In this case, however, the fate of the "fledgling" was known because the deer caught it while it was still in camera view; it survived $<10$ sec outside the nest (Pietz and Granfors 2000b). Forced fledging occurred at nearly $20 \%$ of our nests that were visited by predators and accounted for about $10 \%$ of young that were classified as fledged (Table 1.2; Pietz et al., chapter 4, this volume).

People checking nests also can cause premature or forced fledging. In one case, three Claycolored Sparrow nestlings stayed still while an observer was at the nest, but they all left the nest 
less than a minute after the person departed (table 3 in Pietz and Granfors 2000a). How forced fledging affects survival of those individuals is seldom known. Certainly, if nestlings are sufficiently ambulatory, forced fledging may be advantageous for nestling survival (Lima 2009).

Camera studies have revealed that the determination of nest fates is not always as clear-cut as depicted in the literature. As more studies collect nest data using video, researchers may need to set new standards for terminology and for classifying nest and nestling fates.

\section{PREDATOR IDENTIFICATION AND ECOLOGY}

Researchers have investigated many factors that potentially affect nest predation. In this extensive literature, there are studies that draw opposite conclusions regarding the effects of just about every factor tested-including nest concealment, nest stage, habitat edge, and landscape characteristics (e.g., references in Pietz and Granfors 2000a, Jones and Dieni 2007). One likely explanation for these conflicting results is that the predator communities differed among studies. Before we can understand the ecological factors and underlying mechanisms that govern nest predation, we must first know who the predators are (Lahti 2009; Weidinger 2009, 2010; Benson et al. 2010; Thompson and Ribic, chapter 2, this volume). Video surveillance at nests has helped researchers to do this.

Camera studies have revealed a surprising diversity of predators at grassland passerine nests. For example, in the North Dakota and Minnesota studies (1996-2001), there were 16 different predators identified to the level of genus or species, including 11 mammals, four birds, and one snake (Table 1.3). Similar levels of diversity were found in other grassland studies (Table 1.4; Davis et al., chapter 14 , this volume). In addition to confirming culpability by species assumed to be nest predators, camera studies have documented unsuspected nest predators, such as jumping mice (Zapus spp.) and white-tailed deer (Pietz and Granfors 2000a, 2000b), as well as cattle (Bos taurus) (Nack and Ribic 2005).

Video data have allowed researchers to start exploring how nest predator communities vary at multiple spatial scales. Grassland camera studies across several states, from Wisconsin to Montana and south to Nebraska, have illuminated some regional similarities and differences in predator communities (Table 1.4). Unsurprisingly, raccoons (Procyon lotor) were documented more often at eastern study sites (e.g., Renfrew and Ribic 2003), where the mix of row-crop agriculture [particularly corn (Zea mays)] and woodlands provides quality habitat for raccoons (Dijak and Thompson 2000). Some differences in predator communities reflect latitudinal ranges of taxa. For example, in the more northerly grasslands (Montana, North Dakota, and Minnesota), snakes accounted for less than $5 \%$ of nest predation events in which predators were identified, and these all were by gartersnakes (Thamnophis spp.) (Table 1.4). Farther south, however, the number of snake species and the proportion of snake predations increased markedly. For instance, in Nebraska and Iowa, snake species accounted for more than one-third of nest predations (Table 1.4). The disparity in prevalence of snake predation between cool and warm climates has been documented beyond grasslands (King and DeGraaf 2006). At smaller spatial scales, researchers are just beginning to investigate how predator communities differ among different grassland habitats (Ribic et al., chapter 10 , this volume). Understanding how predator communities vary spatially can be used to help guide grassland bird conservation efforts (Thompson and Ribic, chapter 2, this volume).

Predator communities also can vary temporally, such as across seasons and years. On an extremely long temporal scale, distributions of some snake species and other nest predators that are currently limited by temperature (e.g., fire ants) may change as a result of warming associated with climate change. At the opposite extreme, video surveillance has allowed researchers to examine predation at much finer temporal scales by pinpointing the exact time that predation events occur. This information has prompted new ways of looking at predation ecology.

Knowing the time of predation allows researchers to explore differences between nocturnal and diurnal nest predators. For example, predators hunting during the day have more visual cues available to them, whereas nocturnal predators probably rely more on scent. This led us (the authors) to expect that diurnal predators would find nests with open bowls more easily than nests with covered bowls, but that nest type would be less likely to matter to nocturnal predators. 
TABLE 1.3

Predators documented at grassland passerine nests monitored with video surveillance systems in

North Dakota and Minnesota during 1996-2001.

\begin{tabular}{|c|c|c|c|c|c|c|c|}
\hline Predator & 1996 & 1997 & 1998 & 1999 & 2000 & 2001 & Total \\
\hline Franklin's ground squirrel & & 5 & & & & 1 & 6 \\
\hline Thirteen-lined ground squirrel & & 8 & 3 & 8 & 1 & & 20 \\
\hline Jumping mouse & 2 & & & & & & 2 \\
\hline Deer mouse & & 1 & 1 & & & & 2 \\
\hline Unidentified mouse/vole & & & & 2 & & & 2 \\
\hline Coyote or red fox & 1 & & & & & & 1 \\
\hline Red fox & & & & & 1 & & 1 \\
\hline Long-tailed weasel & 1 & & & & & & 1 \\
\hline Ermine & & & & & 1 & & 1 \\
\hline Least weasel or ermine & & & & & 1 & & 1 \\
\hline American badger & & 2 & 1 & 2 & 1 & & 6 \\
\hline Striped skunk & & & & & 1 & 2 & 3 \\
\hline Raccoon & & & & 1 & & & 1 \\
\hline White-tailed deer & 1 & 1 & 1 & 1 & & 2 & 6 \\
\hline Northern Harrier & & 1 & & & 2 & 1 & 4 \\
\hline Buteo hawk & & 1 & 1 & & & & 2 \\
\hline American Kestrel & & & & & 1 & & 1 \\
\hline Brown-headed Cowbird & 1 & 1 & 1 & 4 & 1 & 1 & 9 \\
\hline Plains gartersnake & & & 1 & 1 & & & 2 \\
\hline Gartersnake & & & & & & 1 & 1 \\
\hline Unidentified & & 3 & & 2 & 1 & 1 & 7 \\
\hline Total predation events & 6 & 23 & 9 & 21 & 11 & 9 & 79 \\
\hline Total nests with cameras & 17 & 52 & 29 & 35 & 27 & 28 & 188 \\
\hline
\end{tabular}

NOTES: In 1996 and 1997, data were collected in Stutsman and Barnes counties, southeastern North Dakota (Pietz and Granfors 2000a). In 1998 and 1999, data were collected at J. Clark Salyer National Wildlife Refuge, Bottineau and McHenry counties, northcentral North Dakota, in collaboration with U.S. Fish and Wildlife biologists (Grant et al. 2006). In 2000 and 2001, data were collected at several sites in Polk County, northwestern Minnesota, in collaboration with Maiken Winter and Douglas H. Johnson's evaluation of Bird Conservation Areas (Winter et al. 2000, 2001, 2006). See Figure 2.1 of Thompson and Ribic (chapter 2, this volume) for a map of the counties in which data were collected. Scientific names of predators are given in Table 1.4. We defined a predation event as any nest visit resulting in removal or destruction of $\geq 1$ egg or nestling by a single individual (or species, if individuals could not be distinguished). In 2001, a Northern Harrier removed a nestling but did not eat it; the nestling later died outside the nest bowl, so we considered this a predation event. Scavenging events (1997 jumping mouse and 1996 red fox) and forced-fledging events (1999 unidentified mouse/vole and 2000 plains gartersnake) are not included in the table. Some nests were visited by multiple predators: one nest was depredated by both a thirteen-lined ground squirrel and an unidentified mouse or vole; one was depredated by both a Northern Harrier and a striped skunk; and two nests were visited by other predators/scavengers after visits by cowbirds.

To test this idea, we determined the time when a predator first removed (or destroyed) an egg or nestling from a nest. We called this the "initial predation" (sensu Pietz and Granfors 2000a) and, because it likely reflected conditions under which the predator found the nest, we used it as a measure of predation risk. We calculated separate rates of initial predation for day and night, using nest data from our North Dakota and Minnesota studies (1996-2001). As predicted, open nests tended to be more vulnerable than covered nests during the day, whereas at night predation risks 
TABLE 1.4

Predators documented at grassland passerine nests monitored with video surveillance systems during several studies in the northern prairies and the Midwest.

\begin{tabular}{|c|c|c|c|c|c|c|}
\hline Common name & Scientific name & Montana & North Dakota & Minnesota & Nebraska/Iowa & Wisconsin \\
\hline Mammals & & & & & & 3 \\
\hline Virginia opossum & Didelphis virginiana & & & & & \\
\hline Franklin's ground squirrel & Poliocitellus franklinii & & 5 & 1 & 1 & \\
\hline Thirteen-lined ground squirrel & Ictidomys tridecemlineatus & & 19 & 1 & 3 & 22 \\
\hline Jumping mouse & Zapus spp. & & 2 & & & \\
\hline Vole & Microtus spp. & & & & & 4 \\
\hline Deer or white-footed mouse & Peromyscus spp. & 1 & 2 & & 2 & \\
\hline Mouse or vole & & & 2 & & & 1 \\
\hline Domestic cat & Felis catus & & & & & 2 \\
\hline Coyote & Canis latrans & & & & & 3 \\
\hline Domestic dog & Canis lupus familiaris & & & & & 1 \\
\hline Red fox & Vulpes vulpes & & & 1 & & 1 \\
\hline Fox or coyote & & & 1 & & & 2 \\
\hline Ermine & Mustela erminea & & & 1 & & \\
\hline Long-tailed weasel & Mustela frenata & & 1 & & & \\
\hline Least weasel & Mustela nivalis & & & 1 & & 1 \\
\hline Weasel & Mustela spp. & & & & & 2 \\
\hline American mink & Neovison vison & & & & 1 & \\
\hline American badger & Taxidea taxus & & 5 & 1 & & 3 \\
\hline Striped skunk & Mephitis mephitis & & & 3 & & 16 \\
\hline Raccoon & Procyon lotor & & 1 & & 6 & 19 \\
\hline White-tailed deer & Odocoileus virginianus & & 4 & 2 & & 4 \\
\hline Domestic cattle & Bos taurus & & & & & 4 \\
\hline
\end{tabular}


Northern Harrier

Red-tailed Hawk

Buteo hawk

American Kestrel

Western Meadowlark

Eastern Meadowlark

Brown-headed Cowbird

Reptiles

North American racer

Milksnake

Western foxsnake

Bullsnake

Gartersnake
Circus cyaneus

Buteo jamaicensis

Buteo spp.

Falco sparverius

Sturnella neglecta

Sturnella magna

Molothrus ater

Coluber constrictor

Lampropeltis triangulum

Mintonius vulpinus

Pituophis catenifer sayi

Thamnophis spp.
3

1
2

5

9

2

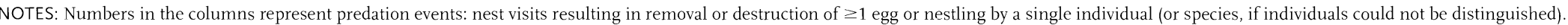

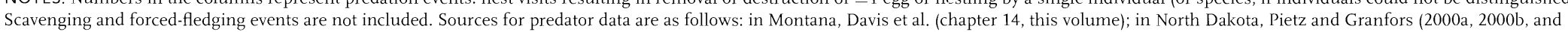

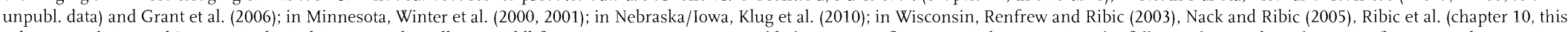

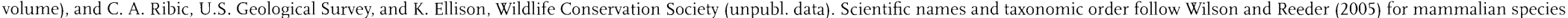

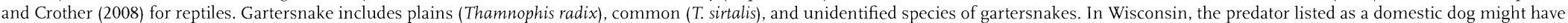
been a coyote. 


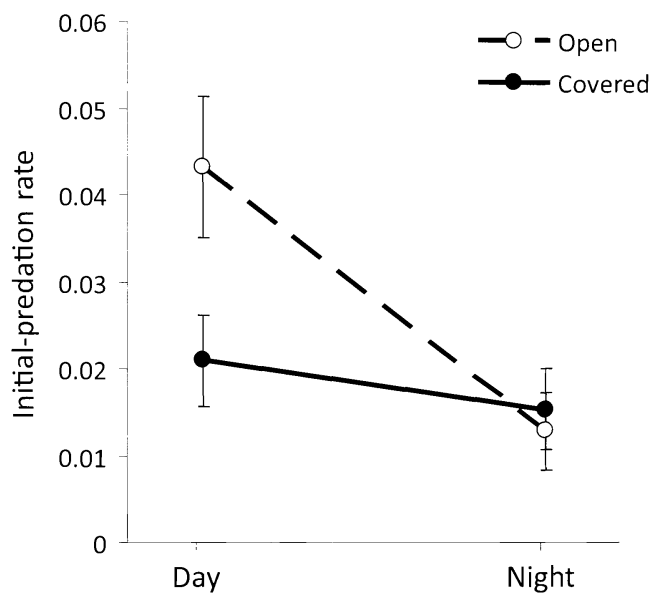

Figure 1.2. Initial-predation rates during day and night for nests that were and were not covered by vegetation (open vs. covered), from a sample of grassland passerine nests monitored with video surveillance systems in North Dakota and Minnesota during 1996-2001. Mean difference in initialpredation rates between open and covered nests during the day was $0.022 \pm 0.010 \mathrm{SE}\left(\chi^{2}{ }_{1}=5.26, P=0.02\right)$ and during the night was $0.003 \pm 0.006\left(\chi^{2}{ }_{1}=0.15, P=0.69\right)$. Sample sizes for open and covered nests were 718 and 625 camera nest-days (i.e., number of days active nests were monitored with cameras), respectively.

(i.e., initial-predation rates) for the two nest types were similar (Fig. 1.2). The same result was found in an earlier analysis using just 1996-1997 data (Pietz and Granfors 2000a). In that paper, daily predation rates also were reported for nearly 300 nests that were monitored without video surveillance (i.e., non-camera nests); no difference was detected between open and covered non-camera nests $\left(\chi_{1}^{2}=0.00, P=0.98\right)$, suggesting that predation risk associated with nest cover may only be detectable if diurnal and nocturnal predation can be separated.

The ability to separate diurnal and nocturnal predation events may contribute to deciphering ecological phenomena in unexpected ways. For example, when Roper and Goldstein (1997) tested the Skutch hypothesis that activity at nests increases nest predation risk (Skutch 1949, 1985), they expected to find greater nest predation rates during the nestling stage than during incubation. They found higher frequencies of nest visits by adult birds during the nestling stage than during incubation, but daily survival rates did not differ between the two nest stages. They surmised that this lack of support for the link between nest activity and predation could be explained by the previously unrecognized importance of predation by a nocturnal mammal, which they assumed did not use bird activity to locate nests.

Now video data can be used to help assess the relative importance of nocturnal versus diurnal predation and to test hypotheses related to activity at nests (e.g., Muchai and du Plessis 2005). Knowing the time of predation also allows researchers to explore whether brood age affects predation risk. We tested some of these ideas with nest data from our North Dakota and Minnesota studies (1996-2001). We used initial-predation rates as a measure of predation risk and used brood age as a surrogate for daytime activity at the nest. We expected daytime initial-predation rates to increase with brood age, because some studies have shown that daytime activity of parents and nestlings tends to increase as nestlings grow (e.g., provisioning rates increase with brood age; Goodbred and Holmes 1996, Dohms 2009). We did not expect nocturnal initial-predation rates to increase with brood age, however, because activity at the nest, at all brood ages, typically ceases at night (Roper and Goldstein 1997; authors, unpubl. data). In our sample, nestlings were more likely to be depredated during the day than at night, but we did not find an increase in initial-predation rate with brood age for either day or night (Fig. 1.3; day: $r_{s}=-0.07, P=0.85$; night: $\left.r_{s}=0.20, P=0.57\right)$. Our sample for some brood ages may have been too small to test for this pattern, or the assumption that activity at the nest increases all the way through fledging age may not be true (e.g., see Adler 2010). Video data can be used to examine this assumption, for example, by quantifying adult visits to nests as the nestlings age. Note that we lumped several species in our analysis because of small sample sizes, but we recognize that activity (e.g., provisioning rates) may not relate to nestling age in the same way for all species. In any case, the hypothesis that brood age affects vulnerability to predation needs further testing.

\section{EVALUATING STANDARD METHODS}

Video surveillance has helped researchers evaluate several standard methods used to study nesting biology, including those used to assign nest fates, causes of nest failure, and (for depredated nests) types of predators. The standard way of determining nest fate is to visit the nest every few days, using nest contents, sign at the nest (including 


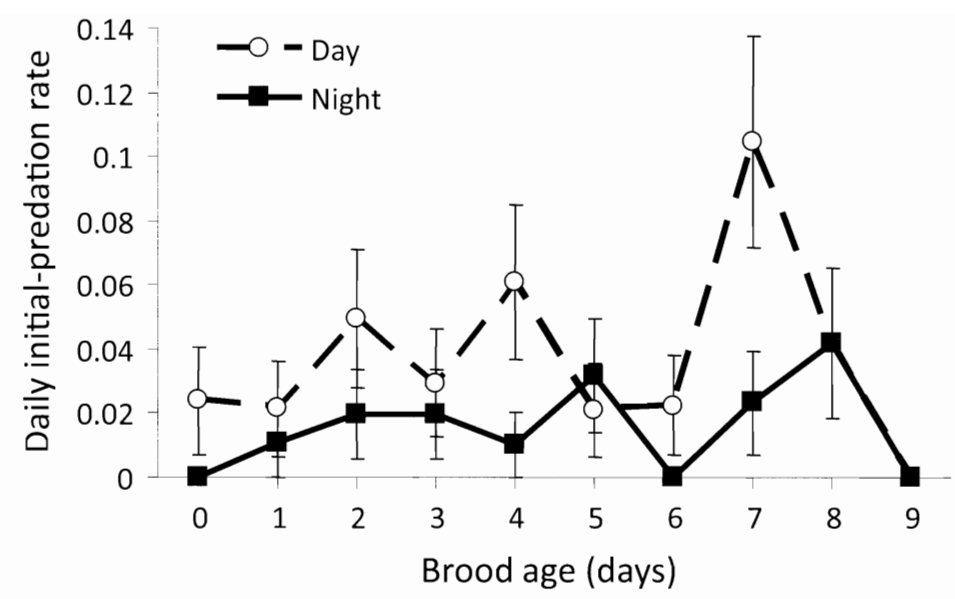

Figure 1.3. Diurnal and nocturnal initial-predation rates $(n=130$ nests, 876 camera nest-days $)$ for broods aged $0-9$ days, from a sample of grassland passerine nests monitored with video surveillance systems in North Dakota and Minnesota during 1996-2001. Vertical lines represent \pm 1 SE. Brood age was calculated using the hatch day of the first egg as day 0.

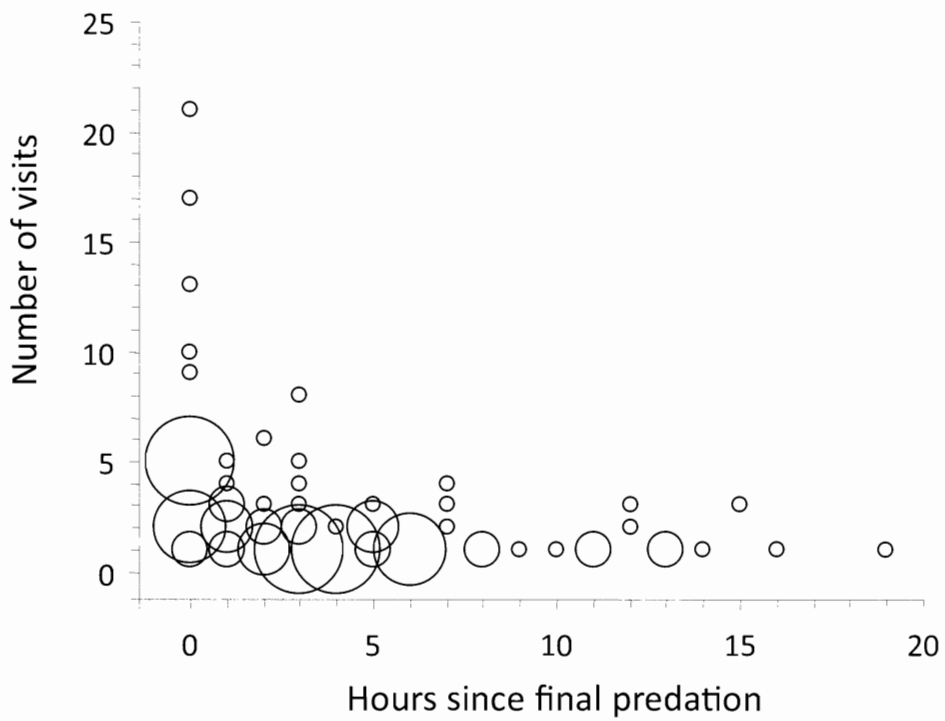

Figure 1.4. Parental nest attendance (i.e., visits) after final predation (i.e., when no viable contents remained in nest), from a sample of grassland passerine nests $(n=20)$ monitored with video surveillance systems in North Dakota, 1996-1997. Larger circles represent more nests. Hours on the $x$-axis represent hourly time intervals (e.g., $0=$ within the first hour; $1=$ within second hour). Nests with zero parental visits after the final predation event were not included.

condition of the nest and nest vicinity), and behavior of parent birds to decide if the nest was successful. Earlier video data showed that initial-predation rate tended to increase with nestling age (Pietz and Granfors 2000a), and many nests were depredated when nestlings were close to fledging age (Pietz and Granfors, unpubl. data). At this stage, depredated and fledged nests may be impossible to tell apart. Even the behavior of parent birds can be misleading. Pietz and Granfors (2000a, unpubl. data) found that parents continued to visit their nests, often carrying food, for several hours after all nest contents had been removed by predators (Fig. 1.4). Visitation rate dropped off quickly, but some parents were still attending nests nearly a day later. Pietz and Granfors (2000a) therefore 
suggested that researchers check adult behavior on more than 1 day if it is used as the basis for classifying nest fate.

Video evidence indicated that some nests failed for reasons other than predation, but the cause of failure might be misconstrued as predation to an observer doing periodic nest checks. For example, when nestlings died at a young age, video showed that the parents sometimes removed the carcasses from the nest (Pietz and Granfors 2000a, Kirkpatrick et al. 2009), resulting in the appearance of predation or partial predation. Another example (Pietz and Granfors 2000a, unpubl. data), involving a Western Meadowlark (Sturnella neglecta) nest in North Dakota, illustrates how difficult it can be to correctly assess cause of failure from nest checks. The meadowlark adults left their five-egg clutch unattended for several hours following human disturbance near the nest site. Then a Brown-headed Cowbird (Molothrus ater) entered the nest bowl, tossed three eggs out of the nest, and punctured holes in the other two eggs. That night, insects scavenged contents from those two eggs, and the following night a red fox (Vulpes vulpes) scavenged the remaining egg contents (and likely removed the three eggs that the cowbird had tossed outside of camera view). When Pietz revisited the site, the only remains were two eggs' shells that looked similar to those known to have been depredated by small mammals (Pietz, pers. obs.).

Prior to camera studies, numerous authors claimed to be able to identify types of nest predators based on the condition of the nest after predation (e.g., Best 1978, Best and Stauffer 1980, Wray et al. 1982, Hoover et al. 1995, Patterson and Best 1996, Christman and Dhondt 1997). Pietz and Granfors (2000a) found that none of their generalizations were valid in North Dakota grasslands. No sign was left at most nests, including those depredated by large mammals. Furthermore, Pietz and Granfors (2000a) found considerable variability within species and overlap among species when they did leave sign (see also Sargeant et al. 1998). Sign can be misleading as well as ambiguous. In Minnesota, for example, a Savannah Sparrow nest from which a four-egg clutch disappeared was found to be surrounded by deer tracks when the nest was checked, but the videotape showed that the eggs had been removed by a male Northern Harrier (Circus cyaneus) (Pietz, unpubl. data). Thus, even when sign appears obvious, it may lead to the wrong conclusion. Many other camera studies, in several habitats and ecosystems, have shown that sign is unreliable for assigning predator types at passerine nests (e.g., Thompson et al. 1999, McCallum and Hannon 2001, Williams and Bohall Wood 2002, Liebezeit and George 2003, Thompson and Burhans 2003) and non-passerine nests (Ratz et al. 1999, MacDonald and Bolton 2005, Coates et al. 2008, White et al. 2010).

Some variation in nest damage by predators might be related to nest height. In North Dakota, for example, a Buteo hawk ripped a Clay-colored Sparrow nest out of a small shrub, completely destroying the nest (Pietz and Granfors 2000a, unpubl. data). Hawks did not appear to damage any of the six ground nests from which they removed eggs or young (Pietz, unpubl. data). Nest predators, in general, were less likely to damage nests that were on the ground than nests that were above the ground (Pietz and Granfors 2000a). This makes sense, given that nests on the ground are easier to reach for most predators and have more structural support than nests that are off the ground and attached to vegetation.

As suggested in an earlier section, video nest surveillance has allowed a new approach to the study of predation risk. The use of initial-predation rate provides a better measure of predation risk (e.g., relative to nest stage, nestling age) than does daily survival rate or daily predation rate (Pietz and Granfors 2000a). Daily survival rate is affected by sources of nest loss other than predation and can be affected by misclassified nest fates. The standard daily predation rate (which we refer to as final-predation rate) only includes nests that have lost all their contents and is associated with the time and conditions when loss of the last viable nest contents was detected. Initial predation, on the other hand, more likely coincides with the time and conditions under which a predator first discovered the nest. If partial predation is common, the initial and final daily predation rates could be substantially different.

Video nest surveillance also has provided a means to verify natural fledging ages (Pietz et al., chapter 4, this volume). For most species, fledging ages published in the literature (e.g., Ehrlich et al. 1988, Baicich and Harrison 1997) are based on data from researchers visiting nests. However, as mentioned earlier, video data have shown that fledging can be precipitated by a nest visit (e.g., table 3 in Pietz and Granfors 2000a). If 
researchers underestimate average fledging ages, it could cause them to conclude that failed nests had fledged and, thus, overestimate nest survival.

Video surveillance also offers a means to evaluate impacts of researcher activities at nests. For example, video could allow researchers to gauge parental reactions to markers used on nestlings and data-collecting devices placed in nests (e.g., artificial-egg thermistors or camera triggers). Some studies already have used nest video for such purposes. For example, Fisher et al. (2010) documented that adult Sprague's Pipits (Anthus spragueii) pulled some radio-marked nestlings from their nests while attempting to remove the nestlings' transmitters. Little et al. (2009) used video data to assess the response of adult Bobolinks (Dolichonyx oryzivorus) to neck ligatures on their nestlings. Ibáñez-Álamo and Soler (2010) identified nest-predator communities at their study sites with nest video, and then used this information to develop an appropriate experimental design to evaluate effects of nest visits by researchers on predation rates. Contrary to traditional ideas, they demonstrated that investigator activities can reduce nest predation.

\section{PREDATOR-PREY BEHAVIOR}

Video nest surveillance allows observation of predator and prey behavior and predator-prey interactions that are difficult or impossible to document any other way in grasslands. For example, camera studies have documented multiple individuals (of the same or different species) depredating the

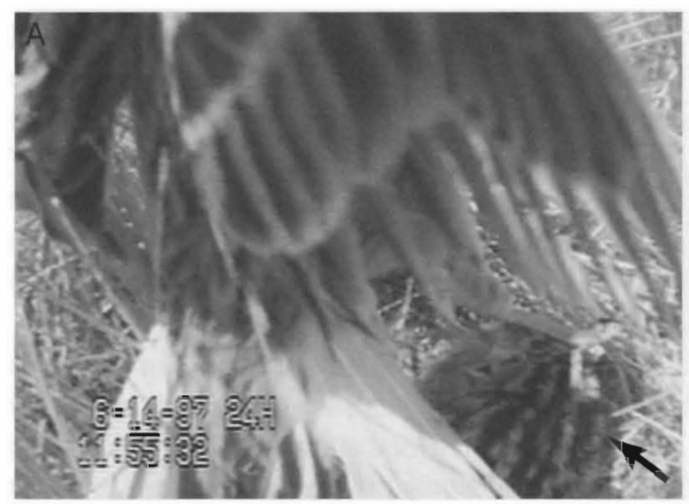

same nest (e.g., Table 1.3; Davis et al., chapter 14, this volume, Ellison and Ribic, chapter 12, this volume). Camera studies have also revealed multiple factors that can lead to partial predation. Smaller predators sometimes removed eggs or nestlings over multiple days (Pietz and Granfors 2000a, Davis et al., chapter 14, this volume). In the latter case, some nestlings could survive to fledge even though their nest mates were eaten on earlier predator visits. As discussed previously, partial predation also resulted when predators ate some young and induced forced fledging of others (if those nests are classified as successful). As discussed below, other partial predations may have resulted because parents successfully defended their nests.

Because cameras in grasslands typically are set close to nests, many instances of adult nest defense may have occurred outside the camera's field of view. Nevertheless, numerous cases of adult birds attacking predators have been documented on video (e.g., Fig. 1.5a). Camera systems have captured nest defense by ten species of grassland-nesting passerines against 11 species of mammalian, avian, and reptilian predators (Pietz and Granfors 2005, Davis et al., chapter 14, this volume, Ellison and Ribic, chapter 12, this volume). Defense occurred during both day and night, and was directed at mice, ground squirrels, a raccoon, a long-tailed weasel (Mustela frenata), Brown-headed Cowbirds, and snakes.

Camera systems have documented both the risks and rewards of nest defense. For example, after unsuccessfully defending four of her five

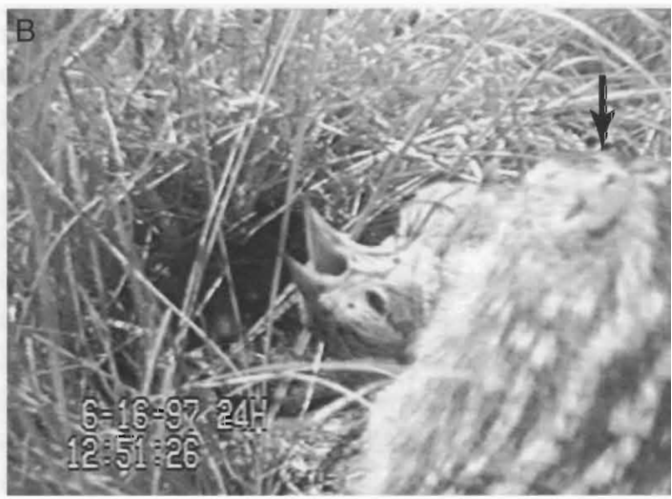

Figure 1.5. Images from videotape of a Chestnut-collared Longspur (Calcarius ornatus) nest monitored in North Dakota during 1997: (a) The female longspur attacked a thirteen-lined ground squirrel (Ictidomys tridecemlineatus) that was removing a nestling from her nest; despite her defense, a ground squirrel removed four of her five nestlings over two days. (b) On the third day, a ground squirrel captured, killed, and dragged the adult longspur from her nest. Arrows point to the ground squirrel in both images. 
suggested that researchers check adult behavior on more than 1 day if it is used as the basis for classifying nest fate.

Video evidence indicated that some nests failed for reasons other than predation, but the cause of failure might be misconstrued as predation to an observer doing periodic nest checks. For example, when nestlings died at a young age, video showed that the parents sometimes removed the carcasses from the nest (Pietz and Granfors 2000a, Kirkpatrick et al. 2009), resulting in the appearance of predation or partial predation. Another example (Pietz and Granfors 2000a, unpubl. data), involving a Western Meadowlark (Sturnella neglecta) nest in North Dakota, illustrates how difficult it can be to correctly assess cause of failure from nest checks. The meadowlark adults left their five-egg clutch unattended for several hours following human disturbance near the nest site. Then a Brown-headed Cowbird (Molothrus ater) entered the nest bowl, tossed three eggs out of the nest, and punctured holes in the other two eggs. That night, insects scavenged contents from those two eggs, and the following night a red fox (Vulpes vulpes) scavenged the remaining egg contents (and likely removed the three eggs that the cowbird had tossed outside of camera view). When Pietz revisited the site, the only remains were two eggs' shells that looked similar to those known to have been depredated by small mammals (Pietz, pers. obs.).

Prior to camera studies, numerous authors claimed to be able to identify types of nest predators based on the condition of the nest after predation (e.g., Best 1978, Best and Stauffer 1980, Wray et al. 1982, Hoover et al. 1995, Patterson and Best 1996, Christman and Dhondt 1997). Pietz and Granfors (2000a) found that none of their generalizations were valid in North Dakota grasslands. No sign was left at most nests, including those depredated by large mammals. Furthermore, Pietz and Granfors (2000a) found considerable variability within species and overlap among species when they did leave sign (see also Sargeant et al. 1998). Sign can be misleading as well as ambiguous. In Minnesota, for example, a Savannah Sparrow nest from which a four-egg clutch disappeared was found to be surrounded by deer tracks when the nest was checked, but the videotape showed that the eggs had been removed by a male Northern Harrier (Circus cyaneus) (Pietz, unpubl. data). Thus, even when sign appears obvious, it may lead to the wrong conclusion. Many other camera studies, in several habitats and ecosystems, have shown that sign is unreliable for assigning predator types at passerine nests (e.g., Thompson et al. 1999, McCallum and Hannon 2001, Williams and Bohall Wood 2002, Liebezeit and George 2003, Thompson and Burhans 2003) and non-passerine nests (Ratz et al. 1999, MacDonald and Bolton 2005, Coates et al. 2008, White et al. 2010).

Some variation in nest damage by predators might be related to nest height. In North Dakota, for example, a Buteo hawk ripped a Clay-colored Sparrow nest out of a small shrub, completely destroying the nest (Pietz and Granfors 2000a, unpubl. data). Hawks did not appear to damage any of the six ground nests from which they removed eggs or young (Pietz, unpubl. data). Nest predators, in general, were less likely to damage nests that were on the ground than nests that were above the ground (Pietz and Granfors 2000a). This makes sense, given that nests on the ground are easier to reach for most predators and have more structural support than nests that are off the ground and attached to vegetation.

As suggested in an earlier section, video nest surveillance has allowed a new approach to the study of predation risk. The use of initial-predation rate provides a better measure of predation risk (e.g., relative to nest stage, nestling age) than does daily survival rate or daily predation rate (Pietz and Granfors 2000a). Daily survival rate is affected by sources of nest loss other than predation and can be affected by misclassified nest fates. The standard daily predation rate (which we refer to as final-predation rate) only includes nests that have lost all their contents and is associated with the time and conditions when loss of the last viable nest contents was detected. Initial predation, on the other hand, more likely coincides with the time and conditions under which a predator first discovered the nest. If partial predation is common, the initial and final daily predation rates could be substantially different.

Video nest surveillance also has provided a means to verify natural fledging ages (Pietz et al., chapter 4 , this volume). For most species, fledging ages published in the literature (e.g., Ehrlich et al. 1988, Baicich and Harrison 1997) are based on data from researchers visiting nests. However, as mentioned earlier, video data have shown that fledging can be precipitated by a nest visit (e.g., table 3 in Pietz and Granfors 2000a). If 
researchers underestimate average fledging ages, it could cause them to conclude that failed nests had fledged and, thus, overestimate nest survival.

Video surveillance also offers a means to evaluate impacts of researcher activities at nests. For example, video could allow researchers to gauge parental reactions to markers used on nestlings and data-collecting devices placed in nests (e.g., artificial-egg thermistors or camera triggers). Some studies already have used nest video for such purposes. For example, Fisher et al. (2010) documented that adult Sprague's Pipits (Anthus spragueii) pulled some radio-marked nestlings from their nests while attempting to remove the nestlings' transmitters. Little et al. (2009) used video data to assess the response of adult Bobolinks (Dolichonyx oryzivorus) to neck ligatures on their nestlings. Ibáñez-Álamo and Soler (2010) identified nest-predator communities at their study sites with nest video, and then used this information to develop an appropriate experimental design to evaluate effects of nest visits by researchers on predation rates. Contrary to traditional ideas, they demonstrated that investigator activities can reduce nest predation.

\section{PREDATOR-PREY BEHAVIOR}

Video nest surveillance allows observation of predator and prey behavior and predator-prey interactions that are difficult or impossible to document any other way in grasslands. For example, camera studies have documented multiple individuals (of the same or different species) depredating the same nest (e.g., Table 1.3; Davis et al., chapter 14, this volume, Ellison and Ribic, chapter 12, this volume). Camera studies have also revealed multiple factors that can lead to partial predation. Smaller predators sometimes removed eggs or nestlings over multiple days (Pietz and Granfors 2000a, Davis et al., chapter 14, this volume). In the latter case, some nestlings could survive to fledge even though their nest mates were eaten on earlier predator visits. As discussed previously, partial predation also resulted when predators ate some young and induced forced fledging of others (if those nests are classified as successful). As discussed below, other partial predations may have resulted because parents successfully defended their nests.

Because cameras in grasslands typically are set close to nests, many instances of adult nest defense may have occurred outside the camera's field of view. Nevertheless, numerous cases of adult birds attacking predators have been documented on video (e.g., Fig. 1.5a). Camera systems have captured nest defense by ten species of grassland-nesting passerines against 11 species of mammalian, avian, and reptilian predators (Pietz and Granfors 2005, Davis et al., chapter 14, this volume, Ellison and Ribic, chapter 12, this volume). Defense occurred during both day and night, and was directed at mice, ground squirrels, a raccoon, a long-tailed weasel (Mustela frenata), Brown-headed Cowbirds, and snakes.

Camera systems have documented both the risks and rewards of nest defense. For example, after unsuccessfully defending four of her five
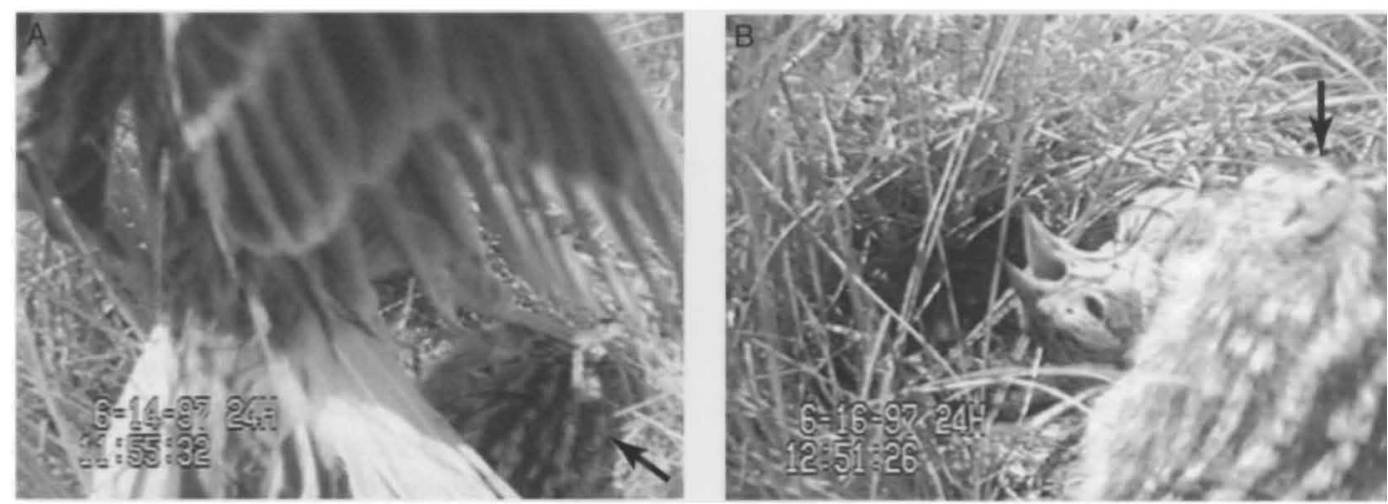

Figure 1.5. Images from videotape of a Chestnut-collared Longspur (Calcarius ornatus) nest monitored in North Dakota during 1997: (a) The female longspur attacked a thirteen-lined ground squirrel (Ictidomys tridecemlineatus) that was removing a nestling from her nest; despite her defense, a ground squirrel removed four of her five nestlings over two days. (b) On the third day, a ground squirrel captured, killed, and dragged the adult longspur from her nest. Arrows point to the ground squirrel in both images. 


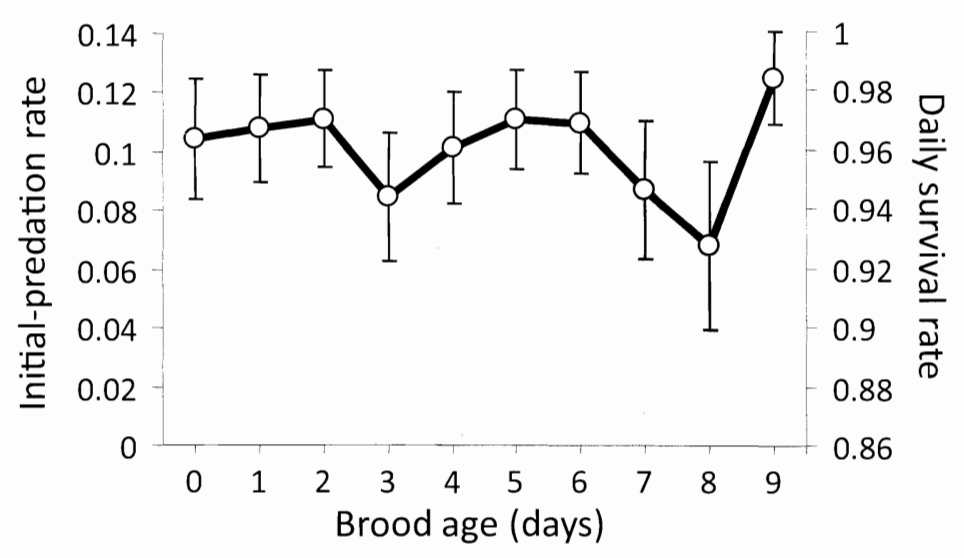

Figure 1.6. Initial-predation rates ( $n=130$ nests, 876 camera nest-days) and nest survival rates ( $n=131$ nests, 936 camera nest-days) for broods aged 0-9 days, from a sample of grassland passerine nests monitored with video surveillance systems in North Dakota and Minnesota during 1996-2001. Vertical lines represent $\pm 1 \mathrm{SE}$. Brood age was calculated using the hatch day of the first egg as day 0 . No nests in this sample were initially depredated when the brood was 9 days old. Both diurnal and nocturnal initial-predation events were included in calculating initial-predation rates.

nestlings from ground-squirrel attacks, a female Chestnut-collared Longspur (Calcarius ornatus) was caught, killed, and dragged from her nest by a thirteen-lined ground squirrel (Ictidomys tridecemlineatus) (Fig. 1.5b; Pietz and Granfors 2005), a species not generally considered a threat to an adult bird. Equally surprising was the apparently successful nest defense by a Clay-colored Sparrow against a long-tailed weasel (Pietz and Granfors 2005), a species known to kill adult birds (Keith 1961). In another case, Brown-headed Cowbird attacks on nestlings elicited vigorous defense by a female Bobolink. The female cowbird picked up three nestlings and carried them away, even while the Bobolink landed on her back and pecked her (Pietz and Granfors 2005). One nestling survived to fledge, however, so by definition, this was a successful nest. Depending on the cowbird's motivation for removing nestlings [e.g., reducing competition for her own young in other nests? (Granfors et al. 2001)], this still could be considered successful predation. Depending on the overall reproductive cost to the Bobolink, this also might be considered successful defense. Nest defense by grassland passerines against snake predators is discussed by Ellison and Ribic (chapter 12, this volume).

Factors that contribute to partial predation (e.g., parental defense, small predator size, and forced fledging) can lead to increased nest survival later in the nesting cycle. The probability that some young will escape from nest predators increases with nestling age (Halupka 1998b, Grant et al. 2005) and may contribute to increased daily nest survival as nestlings get older, a pattern that has been demonstrated for several species (e.g., Grant et al. 2005, Davis et al. 2006). As a result, even studies that showed an increase in predator attacks late in brood rearing (Halupka 1998a, Pietz and Granfors 2000a) did not find a decrease in daily survival rates with nestling age. Here, we examined this phenomenon further, by evaluating initial-predation rates and nest survival rates for broods aged 0-9 days with data from 19962001 (Fig. 1.6). Our results were similar to those found during 1996-1997 for broods aged 0-8 days (Pietz and Granfors 2000a) in that predators initiated more attacks on 7- and 8-d-old broods than on younger broods. However, predators initiated only two attacks on 6-d-old and none on 9-dold broods, demonstrating the variability in our system and the need for larger samples to examine patterns related to brood age. The data set for Figure 1.6 includes only 49 depredated nests spread across ten brood ages. We could have combined some ages (e.g., 0-4 and 5-9 d; for Fig. 1.3 and Fig. 1.6), but this would have obscured the variability that we observed in the raw data.

Probably contributing to this variability was the variety of species in our predator community (Table 1.3), with widely varying diets and foraging 
behaviors, undoubtedly using different sensory cues to find prey. Patterns between predation and nestling age have been found in at least one camera study that focused on a single predator group. Stake et al. (2005) found that snake predation increased through the nesting cycle, reaching the highest rate during the last few days of the nestling period. They concluded that avian activity contributed to foraging success of snakes at their sites.

\section{PARENTAL AND NESTLING BEHAVIORS}

Video nest surveillance is helping to fill gaps in basic knowledge of nesting biology, especially for species that are difficult to observe directly. As noted earlier, nests and activity at nests of many species of grassland birds are difficult or impossible to observe directly. Thus, it is not surprising that the Birds of North America accounts (Poole 2005) for many grassland bird species provide little or no information on many aspects of parental behavior. For example, in the account for Baird's Sparrow (Ammodramus bairdii), Green et al. (2002) state that there is no information about the parents' time on and off the nest during incubation, and the data provided on parental care during brooding are based on observations at three nests more than 80 years ago (Cartwright et al. 1937). In the account for Claycolored Sparrows, Knapton (1994) provides percentages of male and female incubation time based on $3 \mathrm{hr}$ of observations at one nest nearly 50 years ago (Fox 1961). Several chapters in this volume of Studies in Avian Biology illustrate how video data are filling gaps in our knowledge of parental care and nesting biology (e.g., Burnam et al., chapter 7, this volume, Davis and Holmes, chapter 6, this volume, Powell et al., chapter 5 , this volume, Slay et al., chapter 9 , this volume, Smith et al., chapter 8 , this volume). Video data also have provided unexpected information, such as the documentation of a helper at a nest of a Henslow's Sparrow (Ammodramus henslowii, Guzy et al. 2002).

Recent advances in statistical modeling techniques have allowed nest survival to be examined in unprecedented detail (see papers in Jones and Geupel 2007). Use of the logistic-exposure method (Shaffer 2004) has shown complex and sometimes unexpected relationships between nest survival and nest age (Grant et al. 2005, Davis et al. 2006). For example, some grassland passerines showed a drop in daily nest survival through the incubation period (Grant et al. 2005). Video data have been used to explore the possibility that changes in parental nest activity through incubation might be linked to this pattern (Grant et al. 2005; T. L. Shaffer, P. J. Pietz, and D. A. Buhl, U.S. Geological Survey, unpubl. data). Among grassland birds, parental provisioning rates to nestlings of different ages have been documented with video for Grasshopper Sparrows (Ammodramus savannarum) (Adler 2010) and Sprague's Pipits (Dohms 2009). As we have seen, video data can provide a means to explore potential explanations for age- and time-specific variation in passerine nest survival.

Data on behavior of grassland nestlings are even more difficult to obtain than data on behavior of adult grassland passerines. Video surveillance already has provided some information on natural fledging ages for grassland passerines, and on the length of hatching and fledging periods in a sample of nests (e.g., Pietz et al., chapter 4 , this volume). More data need to be collected under natural and experimental conditions to shed light on factors that could influence these phenomena.

Appropriately placed cameras also could allow researchers to evaluate nestling reactions to disturbance and how those reactions change with nestling age. For example, field biologists have observed anecdotally that nestlings of some species respond to humans at the nest by begging when they are young, but remain quiet and still when they are older (T. A. Grant, U.S. Fish and Wildlife Service, pers. comm.; L. D. Igl, U.S. Geological Survey, pers. comm.). Video data could be used to assess if this behavioral change is common and what factors may influence it (e.g., species, habitat, type of disturbance). Interest in how nestling behavior relates to predation risk has prompted numerous experimental studies of begging (e.g., Dickens and Hartley 2007, Dor et al. 2007, Haff and Magrath 2010), but little on nest exodus (Kleindorfer et al. 1996, Lima 2009). Some authors have speculated that well-developed nestlings under attack would not flee the nest (i.e., force fledge) unless their parents directed them to do so (reviewed in Lima 2009). For camera studies of begging behavior or responses to parental calls, researchers would need to incorporate sound recording into their camera systems.

Video surveillance also may provide insights on parental and nestling reactions to severe weather events and other unpredictable disturbances, as 
well as on the impacts of those disturbances. In Montana, for example, when a hailstorm pounded the video-monitored nest of a Baird's Sparrow, the adult fled and the nestlings died (P. J. Gouse, U.S. Fish and Wildlife Service, pers. comm.). This is another example of how knowledge of circumstances might affect nest-fate classification.

\section{CAVEATS}

Video nest surveillance has been instrumental in moving the field of avian ecology forward; however, like every tool, it has limitations. As with all studies of active nests, it is important to minimize effects on the nesting birds, for ethical and conservation reasons (e.g., see Fair et al. 2010) and to protect against biasing the data collected. Several researchers (e.g., Pietz and Granfors 2000a, Renfrew and Ribic 2003, Stake and Cimprich 2003) noted that nest abandonment was greater for nests with cameras than for those without cameras, and made adjustments in methods in an effort to reduce these abandonments (Richardson et al. 2009). Because abandonment risk likely varies by species, camera distance, nest age, and other factors, researchers need to evaluate risk within the specific conditions dictated by their study objectives.

For predation studies, researchers should be aware that the presence of cameras (and the associated equipment) might affect nest visitation by some types of predators (Richardson et al. 2009), especially when cameras are placed close to nests. Populations (or individuals) of some species may be attracted or repelled by novel items and human scent (see discussion in Pietz and Granfors 2000a), depending on the extent to which they have had negative interactions with humans (Birkhead 1991:221, Götmark 1992:80) or have become habituated to human presence. Reports persist that the presence of cameras may increase nest survival, especially during incubation (Conner et al. 2010). However, Richardson et al. (2009) reviewed some sources for this bias that are unrelated to predator behaviors (e.g., a nest usually must survive longer to receive a camera and thus be included in the treatment group), and acknowledged that these factors complicate efforts to synthesize camera effects.

Researchers might bias predation data by how they spatially deploy multiple camera systems (Pietz and Granfors 2000a). If nests with cameras are clustered, they will be exposed to fewer individuals (especially of species with large home ranges); the same individual may depredate multiple nests and may learn to associate cameras with nests. Such associative learning has been noted for some predators that ostensibly linked nest locations with markers placed up to $5 \mathrm{~m}$ away (e.g., Picozzi 1975, Reynolds 1985).

Richardson et al. (2009:292) listed nine recommendations to "minimize or control for potential bias when using surveillance cameras." Among these was the suggestion to "maintain similar rates of nest visitation for nests with and without cameras." Controlling for visitation rates would be sensible for researchers interested in measuring the effects of just the camera's presence on nest survival rates (e.g., McKinnon and Bêty 2009); however, others may argue that this suggestion defeats one of the original purposes of video surveillance, namely to acquire data remotely without the disturbance of repeated nest visits.

Some of the nest predator communities documented by video are trophically complex. For example, many of the species identified in grasslands are opportunistic foragers, and some nest predators can be primary or alternative prey for other predators. In addition, nest predator communities and the species in them can be spatially and temporally dynamic for many reasons, including food availability, changes in human land use, and disease. For example, during our studies in North Dakota and Minnesota, skunk and canid populations in some areas were reduced by rabies and mange, respectively (Pietz and Granfors 2000a). Researchers need to keep this dynamic complexity in mind so that their conclusions are drawn at the correct temporal and spatial scales. Temporal and spatial variability in our predator community in northern grasslands is illustrated in Table 1.3; for example, among the six years (areas) of data collection shown, nest predation by ground squirrels ranged from absent to dominant.

Another factor to keep in mind is that identification of individuals may not be possible without auxiliary markers. Even with color imagery, it may not be possible to distinguish male from female parents, or the parent from a non-parent conspecific (e.g., a helper; Guzy et al. 2002), especially for monomorphic species without sexually dichromatic plumage. Similarly, multiple appearances 
at a nest by the same predator species may involve one or more individuals. Naturally occurring differences sometimes can be used to separate ndividuals (e.g., a molted feather, a scar, or body size). In general, however, researchers should be careful not to make unsubstantiated assumptions about parent birds or predators.

Video data acquired by monitoring nests with miniature cameras have improved our ability to address old questions, allowed us to confirm or efute long-held assumptions, and opened up entirely new areas of investigation. For example, video data are uniquely suited to document some emporal aspects of predation (e.g., time of day, nest age) and have provided new ways of measuring predation risk. The promise of video data from nests, however, depends on researchers making the effort to properly adapt camera systems to their situation. Every tool has potential shortcomings and, to minimize these, investigators must take care to design a system that suits the species, habitats, and environments in which they work. To avoid potential biases and erroneous conclusions, and to improve the quality and value of findings, care also must be taken in analyzing and interpreting video data. We hope this chapter and others in this volume will help those planning to collect and those currently collecting video data at nests.

\section{ACKNOWLEDGMENTS}

We thank our research collaborators T. J. Anderson, K. S. Ellison, P. J. Gouse, T. A. Grant, M. J. Guzy, D. H. Johnson, S. L. Jones, E. M. Madden, J. L. Nack, R. B. Renfrew, D. W. Sample, J. A. Shaffer, and M. Winter. We also thank all the field technicians who helped collect the data used in this paper. D. A. Buhl and G. A. Sargeant provided help with statistical analyses. Camera systems were built by J. Christensen, J. Dadisman, K. S. Ellison, R. Fuhrman, and D. K. Garcelon. Mention of trade names or commercial products does not constitute endorsement for use by the U.S. government. Financial support was provided by U.S. Geolosical Survey, Northern Prairie Wildlife Research Center, U.S. Fish and Wildlife Service (Regions 6 and 3 Nongame Bird Conservation Programs, and J. Clark Salyer National Wildlife Refuge), and Wisconsin Department of Natural Resources. L. D. Igl, S. L. Jones, and F. R. Thompson III provided thoughtful reviews of earlier versions of this paper. Special thanks to L. D. Igl, who provided references and advice throughout the development of this chapter.

\section{LITERATURE CITED}

Adler, J. 2010. Provisioning behavior of male and female Grasshopper Sparrows. M.S. thesis, Eastern Kentucky University, Richmond, KY.

Baicich, P. J., and C. J. O. Harrison. 1997. A guide to the nests, eggs, and nestlings of North American birds. Academic Press, San Diego, CA.

Basore, N. S., L. B. Best, and J. B. Wooley, Jr. 1986. Bird nesting in Iowa no-tillage and tilled cropland. Journal of Wildlife Management 50:19-28.

Benson, T. J., J. D. Brown, and J. C. Bednarz. 2010. Identifying predators clarifies predictors of nest success in a temperate passerine. Journal of Animal Ecology 79:225-234.

Best, L. B. 1978. Field Sparrow reproductive success and nesting ecology. Auk 95:9-22.

Best, L. B., and D. F. Stauffer. 1980. Factors affecting nesting success in riparian bird communities. Condor 82:149-158.

Birkhead, T. 1991. The magpies. T. \& A. D. Poyser, London, UK.

Cartwright, B. W., T. M. Shortt, and R. D. Harris. 1937. Baird's Sparrow. Transactions of the Royal Canadian Institute 21:153-197.

Christman, B. J., and A. A. Dhondt. 1997. Nest predation in Black-capped Chickadees: how safe are cavity nests? Auk 114:769-773.

Coates, P. S., J. W. Connelly, and D. J. Delehanty. 2008. Predators of Greater Sage-Grouse nests identified by video monitoring. Journal of Field Ornithology 79:421-428.

Conner, L. M., J. C. Rutledge, and L. L. Smith. 2010. Effects of mesopredators on nest survival of shrub-nesting songbirds. Journal of Wildlife Management 74:73-80.

Crother, B. I. (editor). 2008. Scientific and standard English names of amphibians and reptiles of North America north of Mexico. Herpetological Circular No. 37. Society for the Study of Amphibians and Reptiles, Salt Lake City, UT.

Davis, S. K., R. M. Brigham, T. L. Shaffer, and P. C. James. 2006. Mixed-grass prairie passerines exhibit weak and variable responses to patch size. Auk 123:807-821.

Dickens, M., and I. R. Hartley. 2007. Stimuli for nestling begging in Blue Tits Cyanistes caeruleus: hungry nestlings are less discriminating. Journal of Avian Biology 38:421-426.

Dijak, W. D., and F. R. Thompson III. 2000. Landscape and edge effects on the distribution of mammalian predators in Missouri. Journal of Wildlife Management 64:209-216.

Dohms, K. M. 2009. Sprague's Pipit (Anthus spragueii) nestling provisioning and growth rates in native and planted grasslands. M.S. thesis, University of Regina, Regina, Saskatchewan, Canada. 
Dor, R., H. Kedar, D. W. Winkler, and A. Lotem. 2007. Begging in the absence of parents: a "quick on the trigger" strategy to minimize costly misses. Behavioral Ecology 18:97-102.

Ehrlich, P. R., D. S. Dobkin, and D. Wheye. 1988. The birder's handbook. Simon and Schuster, New York, NY.

Fair, J. M., E. Paul, and J. Jones (editors). 2010. Guidelines to the use of wild birds in research. Third edition. The Ornithological Council, Washington, DC. <http://www.nmnh.si.edu/BIRDNET/guide> (14 April 2010).

Fisher, R. J., K. M. Dohms, and S. K. Davis. 2010. Removal of nestling radio-transmitters by adult Sprague's Pipit (Anthus spragueii). Journal of Ornithology 151:749-753.

Fox, G. A. 1961. A contribution to the life history of the Clay-colored Sparrow. Auk 78:220-224.

Goodbred, C. O., and R. T. Holmes. 1996. Factors affecting food provisioning of nestling Black-throated Blue Warblers. Wilson Bulletin 108:467-479.

Götmark, F. 1992. The effects of investigator disturbance on nesting birds. Current Ornithology 9:63-104.

Granfors, D. A., P. J. Pietz, and L. A. Joyal. 2001. Frequency of egg and nestling destruction by female Brown-headed Cowbirds at grassland nests. Auk 118:765-769.

Grant, T. A., E. M. Madden, T. L. Shaffer, P. J. Pietz, G. B. Berkey, and N. J. Kadrmas. 2006. Nest survival of Clay-colored and Vesper Sparrows in relation to woodland edge in mixed-grass prairies. Journal of Wildlife Management 70:691-701.

Grant, T. A., T. L. Shaffer, E. M. Madden, and P. J. Pietz. 2005. Time-specific variation in passerine nest survival: new insights into old questions. Auk 122:661-672.

Green, M. T., P. E. Lowther, S. L. Jones, S. K. Davis, and B. C. Dale. 2002. Baird's Sparrow (Ammodramus bairdii). Birds of North America No. 638, Academy of Natural Sciences, Philadelphia, PA.

Guzy, M. J., C. A. Ribic, and D. W. Sample. 2002. Helping at a Henslow's Sparrow nest in Wisconsin. Wilson Bulletin 114:407-409.

Haff, T. M., and R. D. Magrath. 2010. Vulnerable but not helpless: nestlings are fine-tuned to cues of approaching danger. Animal Behaviour 79:487-496.

Halupka, K. 1998a. Nest predation in Meadow Pipits Anthus pratensis nesting in natural conditions. Ornis Fennica 75:139-143.

Halupka, K. 1998b. Partial nest predation in an altricial bird selects for the accelerated development of young. Journal of Avian Biology 29:129-133.

Herkert, J. R. 1995. An analysis of midwestern breeding bird population trends: 1966-1993. American Midland Naturalist 134:41-50.
Hill, D. P., and S. G. Sealy. 1994. Desertions of nests parasitized by cowbirds: have Clay-coloured Sparrows evolved an anti-parasite defence? Animal Behaviour 48:1063-1070.

Hoover, J. P., M. C. Brittingham, and L. J. Goodrich. 1995. Effects of forest patch size on nesting success of Wood Thrushes. Auk 112:146-155.

Hussell, D. J. T. 1974. Photographic records of predation at Lapland Longspur and Snow Bunting nests. Canadian Field-Naturalist 88:503-506.

Ibáñez-Álamo, J. D., and M. Soler. 2010. Investigator activities reduce nest predation in Blackbirds Turdus merula. Journal of Avian Biology 41:208-212.

Igl, L. D., and D. H. Johnson. 1997. Changes in breeding bird populations in North Dakota: 1967 to 1992-93. Auk 114:74-92.

Johnson, D. H., and L. D. Igl. 1995. Contributions of the Conservation Reserve Program to populations of breeding birds in North Dakota. Wilson Bulletin 107:709-718.

Johnson, D. H., and M. D. Schwartz. 1993. The Conservation Reserve Program and grassland birds. Conservation Biology 7:934-937.

Jones, S. L., and J. S. Dieni. 2007. The relationship between predation and nest concealment in mixedgrass prairie passerines: an analysis using program MARK. Studies in Avian Biology 34:117-123.

Jones, S. L., and G. R. Geupel (editors). 2007. Beyond Mayfield: measurements of nest-survival data. Studies in Avian Biology No. 34, Cooper Ornithological Society, Camarillo, CA.

Keith, L. B. 1961. A study of waterfowl ecology on small impoundments in southeastern Alberta. Wildlife Monographs No. 6, Wildlife Society, Bethesda, MD.

King, D. I., and R. M. DeGraaf. 2006. Predators at bird nests in a northern hardwood forest in New Hampshire. Journal of Field Ornithology 77:239-243.

Kirkpatrick, C., C. J. Conway, and M. H. Ali. 2009. Sanitation of entire broods of dead nestlings may bias cause-specific nest failure rates. Ibis 151:207-211.

Kleindorfer, S., H. Hoi, and B. Fessl. 1996. Alarm calls and chick reactions in the Moustached Warbler, Acrocephalus melanopogon. Animal Behaviour 51:1199-1206.

Klug, P. E. 2005. The effects of local grassland habitat and surrounding landscape composition on the predators of grassland bird nests. M.S. thesis, University of Nebraska at Omaha, NE.

Klug, P. E., L. L. Wolfenbarger, and J. P. McCarty. 2010. Snakes are important nest predators of Dickcissels in an agricultural landscape. Wilson Journal of Ornithology 122:799-803.

Knapton, R. W. 1994. Clay-colored Sparrow (Spizella pallida). Birds of North America No. 120, Academy of Natural Sciences, Philadelphia, PA. 
Knopf, F. L. 1994. Avian assemblages on altered grasslands. Studies in Avian Biology 15:247-257.

Lahti, D. C. 2009. Why we have been unable to generalize about bird nest predation. Animal Conservation 12:279-281.

Liebezeit, J. R., and T. L. George. 2003. Comparison of mechanically egg-triggered cameras and timelapse video cameras in identifying predators at Dusky Flycatcher nests. Journal of Field Ornithology 74:261-269.

Lima, S. L. 2009. Predators and the breeding bird: behavioral and reproductive flexibility under the risk of predation. Biological Reviews 84:485-513.

Little, L. P., A. M. Strong, and N. G. Perlut. 2009. Aggressive response of adult Bobolinks to neck ligatures on nestlings. Wilson Journal of Ornithology 12:441-444.

MacDonald, M. A., and M. Bolton. 2008. Predation on wader nests in Europe. Ibis 150(Suppl. 1):54-73.

Major, R. E., and G. Gowing. 1994. An inexpensive photographic technique for identifying nest predators at active nests of birds. Wildlife Research 21:657-666

Martin, T. E. 1993. Nest predation among vegetation layers and habitat types: revising the dogmas. American Naturalist 141:897-913.

McCallum, C. A., and S. J. Hannon. 2001. Accipiter predation of American Redstart nestlings. Condor 103:192-194.

McKinnon, L., and J. Bêty. 2009. Effect of camera monitoring on survival rates of high-Arctic shorebird nests. Journal of Field Ornithology 80:280-288.

Muchai, M., and M. A. du Plessis. 2005. Nest predation of grassland bird species increases with parental activity at the nest. Journal of Avian Biology 36:110-116.

Nack, J. L., and C. A. Ribic. 2005. Apparent predation by cattle at grassland bird nests. Wilson Bulletin 117:56-62.

Patterson, M. P., and L. B. Best. 1996. Bird abundance and nesting success in Iowa CRP fields: the importance of vegetation structure and composition. American Midland Naturalist 135:153-167.

Peterjohn, B. G., and J. R. Sauer. 1993. North American Breeding Bird Survey annual summary 19901991. Bird Populations 1:52-67.

Picozzi, N. 1975. Crow predation on marked nests. Journal of Wildlife Management 39:151-155.

Pietz, P. J., and D. A. Granfors. 2000a. Identifying predators and fates of grassland passerine nests using miniature video cameras. Journal of Wildlife Management 64:71-87.

Pietz, P. J., and D. A. Granfors. 2000b. White-tailed deer (Odocoileus viginianus) predation on grassland songbird nestlings. American Midland Naturalist 144:419-422.
Pietz, P. J., and D. A. Granfors. 2005. Parental nest defense on videotape: more reality than "myth." Auk 122: 701-705.

Poole, A. (editor). 2005. The Birds of North America online. Cornell Laboratory of Ornithology, Ithaca, NY. <http://bna.birds.cornell.edu/BNA> (10 June 2008).

Ratz, H., H. Moller, and D. Fletcher. 1999. Predator identification from bite marks on penguin and albatross chicks. Marine Ornithology 27:149-156.

Renfrew, R. B., and C. A. Ribic. 2003. Grassland passerine nest predators near pasture edges identified on videotape. Auk 120:371-383.

Renfrew, R. B., C. A. Ribic, and J. L. Nack. 2005. Edge avoidance by nesting grassland birds: a futile strategy in a fragmented landscape. Auk 122:618-636.

Reynolds, J. D. 1985. Sandhill Crane use of nest markers as cues for predation. Wilson Bulletin 97:106-108.

Richardson, T. W., T. Gardali, and S. H. Jenkins. 2009. Review and meta-analysis of camera effects on avian nest success. Journal of Wildlife Management 73:287-293.

Romig, G. P., and R. D. Crawford. 1995. Clay-colored Sparrows in North Dakota parasitized by Brownheaded Cowbirds. Prairie Naturalist 27:193-203.

Roper, J. J., and R. R. Goldstein. 1997. A test of the Skutch hypothesis: does activity at nests increase nest predation risk? Journal of Avian Biology 28:111-116.

Sargeant, A. B., R. J. Greenwood, M. A. Sovada, and T. L. Shaffer. 1993. Distribution and abundance of predators that affect duck production-Prairie Pothole Region. Resource Publication No. 194. U.S. Department of Interior, Fish and Wildlife Service, Washington, DC.

Sargeant, A. B., M. A. Sovada, and R. J. Greenwood. 1998. Interpreting evidence of depredation of duck nests in the Prairie Pothole Region. U.S. Geological Survey, Northern Prairie Wildlife Research Center, Jamestown, ND, and Ducks Unlimited, Inc., Memphis, TN.

Shaffer, T. L. 2004. A unified approach to analyzing nest success. Auk 121:526-540.

Skutch, A. F. 1949. Do tropical birds rear as many young as they can nourish? Ibis 91:430-455.

Skutch, A. F. 1985. Clutch size, nesting success, and predation on nests of neotropical birds, reviewed. Ornithological Monographs 36:575-594.

Stake, M. M., and D. A. Cimprich. 2003. Using video to monitor predation at Black-capped Vireo nests. Condor 105:348-357.

Stake, M. M., F. R. Thompson III, J. Faaborg, and D. E. Burhans. 2005. Patterns of snake predation at songbird nests in Missouri and Texas. Journal of Herpetology 39:215-222. 
Thompson, F. R., III, and D. E. Burhans. 2003. Predation of songbird nests differs by predator and between field and forest habitats. Journal of Wildlife Management 67:408-416.

Thompson, F. R., III, W. Dijak, and D. E. Burhans. 1999. Video identification of predators at songbird nests in old fields. Auk 116:259-264.

Vickery, P. D., M. L. Hunter, Jr., and J. V. Wells. 1992. Evidence of incidental nest predation and its effects on nests of threatened grassland birds. Oikos 63:281-288.

Weidinger, K. 2009. Nest predators of woodland opennesting songbirds in central Europe. Ibis 151:352360.

Weidinger, K. 2010. Foraging behaviour of nest predators at open-cup nests of woodland passerines. Journal of Ornithology 151:729-735.

White, C. L., L. R. Strauss, and S. K. Davis. 2010. Video evidence of Piping Plover nest predation. Northwestern Naturalist 91:202-205.

Williams, G. E., and P. Bohall Wood. 2002. Are traditional methods of determining nest predators and nest fates reliable? An experiment with Wood Thrushes (Hylocichla mustelina) using miniature video cameras. Auk 119:1126-1132.

Wilson, D. E., and D. M. Reeder (editors). 2005. Mammal species of the world: a taxonomic and geographic reference. Third edition. Johns Hopkins University Press, Baltimore, MD.

Winter, M., D. H. Johnson, J. A. Dechant, T. M. Donovan, and W. D. Svedarsky. 2001. Evaluation of the bird conservation area concept in the northern tallgrass prairie. Annual report: 2001 (version 04MAR2002). Northern Prairie Wildlife Research Center, U.S. Geological Survey, Jamestown, ND. <http://www.npwrc.usgs.gov/resource/birds/ bca2001/index.htm> (15 July 2009).

Winter, M., D. H. Johnson, T. M. Donovan, and W. D. Svedarsky. 2000. Evaluation of the bird conservation area concept in the northern tallgrass prairie. Annual report: 2000 (version 26JAN2001). Northern Prairie Wildlife Research Center, U.S. Geological Survey, Jamestown, ND. <http://www.npwrc.usgs .gov/resource/birds/bca2000/index.htm> (15 July 2009).

Winter, M., D. H. Johnson, J. A. Shaffer, T. M. Donovan, and W. D. Svedarsky. 2006. Patch size and landscape effects on density and nesting success of grassland birds. Journal of Wildlife Management 70:158-172.

Wray, T., II, K. A. Strait, and R. C. Whitmore. 1982. Reproductive success of grassland sparrows on a reclaimed surface mine in West Virginia. Auk 99:157-164. 